\title{
RESEÑA. AS IMAGENS NAS CONFIGURAÇÕES EDUCATIVAS CONTEMPORÂNEAS
}

\author{
REVIEW. AS IMAGENS NAS CONFIGURAÇÕES EDUCATIVAS \\ CONTEMPORÂNEAS \\ REVISÃO. AS IMAGENS NAS CONFIGURAÇÕES EDUCATIVAS \\ CONTEMPORÂNEAS
}

Jerônimo Jorge Cavalcante Silva Universidad del Estado de Bahia, Brasil https://orcid.org/0000-0003-0274-9659

jorgeazul53@gmail.com

Recibido: 25/02/2021 Revisado: 17/03/2021 Aceptado:17/03/2021 Publicado: 01/04/2021

Autor: Antenor Rita Gomes

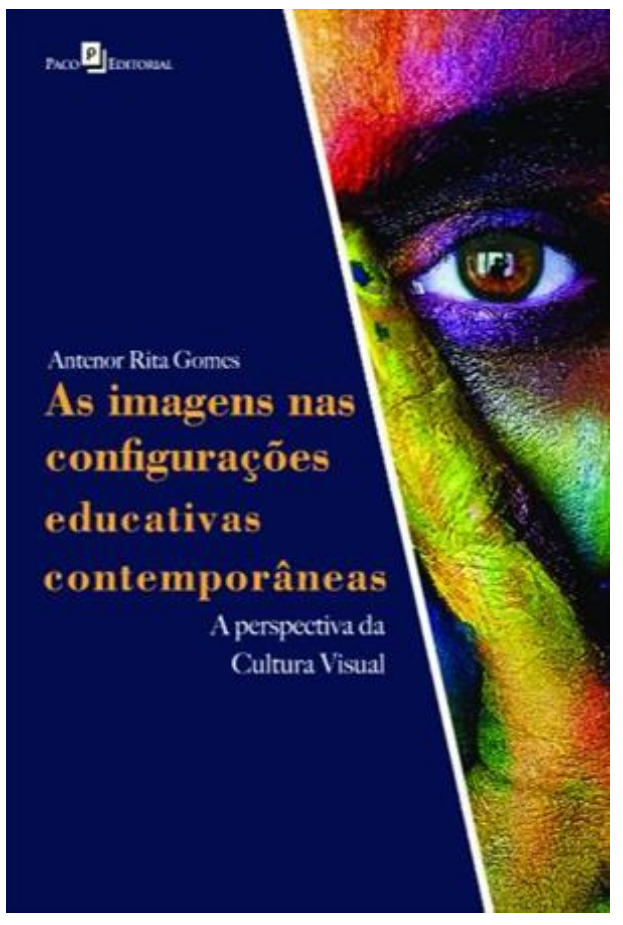

Editorial: Paco Editorial Sia

Año: 2020

Cómo citar esta reseña: Silva, J.J.C. (2021). Reseña. As imagens nas configurações educativas contemporáneas. Hachetetepé. Revista científica en Educación y Comunicación, (22),1-3. https://doi.org/10.25267/Hachetetepe.2021.i22.1303

¿Se ha parado a pensar en el valor y desarrollo que tienen las imágenes en las configuraciones educativas contemporáneas? Tal vez, la respuesta para los que nos dedicamos a la educación puede que sea la de bastante. Su presencia es activa y activista. No se puede eludir que la imagoesfera es parte de la superficie terrestre sobre la que nos desenvolvemos. Pero el docente, en su amplio espectro, ¿posee conocimiento y una visión idónea para su inclusión en la cotidianeidad de su quehacer profesional? En este sentido, la respuesta sería más complicada. 
En un mundo globalizado e impregnado de imágenes, se salpica una necesidad: la de atender al lenguaje y contemplar la presencia en las muchas maneras en que se manifiesta. La cual no se puede medir solo en la cantidad o calidad, sino, igualmente, en la diversidad de darse a conocer, de modo multimodal. Y la educación no puede quedar ajena a ello. No está exenta de esta responsabilidad. Por ello, el profesor y doctor de la Universidad del Estado de Bahía (Brasil), Antenor Rita Gomes, lleva a cabo esta investigación en el marco de un postdoctorado que realizo en la Universidad de Lisboa (2019), junto a su director Fernando Albuquerque.

Desde el comienzo nos llaman poderosamente la atención dos cosas: por un lado, la dedicatoria que acrecienta el interés por leer el presente libro. Está dedicado a "profesores e investigadores de la educación y cultura visual". Evidenciando su ámbito de intervención, estudio y docencia del autor. Y, por el otro, el sumario, que condensa un trabajo en cuatro bloques y entrelaza la intención de dar a comprender la imagen en la contemporaneidad, además de tener presente el contexto lusofalante de Brasil y Portugal.

El conocimiento pasa por saber leer la imagen; aquel pensamiento de Paulo Freire cala profundamente en la labor docente que imagina, pues trabaja con imágenes de realidades posibles. De lo contrario, la imagen sería una fabulación que se diluye en la mera anécdota apreciada solo por la gratificación y siendo motivo hasta de su castigo o prohibición. La imagen en cultura, del mismo modo que es política siguiendo los dictados del zoon politikón del propio Aristóteles; anhelados bastiones de la educación. La manifestación cívica de vivir y educarse en sociedad, como no podría ser de otra forma, pasa por atender a esta manera de producción de sentido, que no está libre de intereses y posibles interpretaciones baladíes que dificultan su comprensión.

En lo contemporáneo se muestra emergente las simplificaciones de crear, transferir o consumir imágenes a la vez que la digitalización y fluidez cultural de la misma (Aparici, 2008). Está claro que se ha abierto un nuevo escenario. No se puede mirar para el otro lado. Se ha de saber mirar y admirar. Estamos ante las dos caras de esta necesidad educativa y cultural de atender a la educación contemporánea. Caminar de la mano de las imágenes no solo para su consumo sino, igualmente, para su producción nos convierten en un apreciado militante de la educación actual que desafía y reclama la justicia de la mejora transdisciplinar.

La imagen está y penetra, convive y convence: del mismo modo que amplía la visión del mundo y dimensiona el aula. Hace falta abordarla en su justa medida, sin olvidarnos que somos homo videns (Sartori, 2002). No se trata solamente de es solo evaluarla; sino considerarla como un bien material que está dentro y fuera del espacio para la educación. Y aquí es cuando pensamos en las pantallas, en lo digital como se refiere el autor. Hoy en día, no se puede concebir las configuraciones educativas contemporáneas sin tener presente la imagen poliédrica.

En poco más de 130 páginas el autor recorre e invita a saber, a detenernos sobre el poder de la imagen. Y su argumentación final se centra sobre la producción académica de Brasil y Portugal. Y siempre con una intención dialogante y sin soslayar las contribuciones que se han producido sobre la cultura visual en el macro marco que se referencia de las diversas configuraciones educativas contemporáneas.

Un trabajo de esta índole no puede acabarse sin un apartado para las consideraciones finales. Con un marcado tinte ideológico y político. En este sentido, resaltaremos una línea argumentativa en su trabajo: "El campo de la Cultura Visual es un campo de conocimiento hibrido y relacional". Un llamamiento a la práctica educativa 
para que se erijan como buenas prácticas. Ya no vale con la simple acepción de prácticas sino que, a partir de ahora, se hace imprescindible lo de buenas prácticas para que requiera y adquiera la dimensión pedagógica que sustenta las intenciones del presente libro.

Un texto cargado de semántica y simbología sobre la imagen (Dussel y Gutiérrez, 2014). No solo en su dimensión poética o pedagógica sino de compromiso profesional. Abrir los ojos es un llamamiento para la educación contemporánea. Cerrar la insensatez de la incomprensión de la imagen en la educación es un recurso que se reivindica.

Bien argumentado, el desatino se diluye entre las acciones que se podrían tildar de bien intencionadas. Ahora hace falta tomar consciencia y obrar en consecuencia. Lejos del albor de la cultura visual invisibilizada, se hace eco la imagen en su relación con la sociedad que la acoge y le da sentido. Hacer pensar sobre esta realidad es un acicate para que el docente del siglo XXI se haga, tal como sugiere el autor, en un "activista visual"... Rodeado de la pos-verdad, la convergencia cultural o la transmedia... Incentivar y mirar a la imagen ahora más y mejor que nunca. No más ciegos educativos. Demos un poco de luz sobre la educación contemporánea. Y que sean las imágenes la que iluminan el foco.

\section{REFERENCIAS BIBLIOGRÁFICAS}

Aparici, R. (2008). Lectura de imágenes en la era digital. De la Torre.

Dussel, I. y Gutiérrez, D. (2014). Educar la mirada: Políticas y pedagogías de la imagen. Manantial.

Gomes, A.R. (2020). As imagens nas configurações educativas contemporâneas. Paco Editorial Sia

Sartori, G. (2002). Homo videns: la sociedad teledirigida. Taurus. 